\title{
4 \\ REFLEXIONES TEÓRICAS \\ SOBRE LA JUDICIALIZACIÓN \\ DE LA POLÍTICA ARGENTINA
}

\author{
Luciano Nosetto (•), 1 \\ CONICET, Universidad de Buenos Aires \\ (Argentina)
}

\section{RESUMEN}

Este artículo propone una reflexión sobre el fenómeno de la judicialización de la política en Argentina, desde la perspectiva disciplinaria de la teoría política. Para ello, se asume una estrategia conceptual y analítica, consistente en desagregar el fenómeno en vista de cuatro tipo de prácticas políticas que resultan alcanzadas por la judicialización, a saber: (1) la canalización de las demandas sociales, (2) el debate público, (3) la legislación y (4) el diseño, ejecución y control de políticas públicas. Tras evaluar estas manifestaciones, se consideran las propuestas de ujusticia deliberativa" y «representación judicial».

\section{PALABRAS CLAVE:}

judicialización, división de poderes, poder judicial.

\section{ABSTRACT}

This article aims at reflecting on the phenomenon of judicialization of politics in Argentina, from the disciplinary point of view of political theory. A conceptual and analytical strategy is developed, in order to identify and analyze four types of political namely, (1) the channeling of social demands, (2) the development of public debate, (3) the legislative process, and (4) the design, implementation, and control of public policies. Once these variants of the phenomenon of judicialization are evaluated, the article concludes by considering the proposals of "deliberative justice" and "judiciary representation".

\section{KEY WORDS:}

judicialization, balance of power, judiciary

(•)E-mail: Inosetto@sociales.uba.ar 